\title{
Determinativproduktion: Fra Brocas afasi til en lingvistisk teori om, hvad grammatik er
}

\author{
Kasper Boye, Sarah Rosenbech Nielsen \\ \& Byurakn Ishkhanyan
}

\begin{abstract}
This paper summarizes recent experiments examining the production of grammatical and lexical determiners in healthy individuals and individuals with agrammatic aphasia. The experiments discussed employ a design in which the Danish grammatical indefinite article en/et is contrasted with the lexical numeral en/et. The results show that articles are harder to produce than numerals. In agrammatic speech the difference is reflected in a higher proportion of omissions of articles. In healthy speech the difference is reflected in increased response times and decreased accurary rates for articles. The results are interpreted in light of a usage-based and functional theory of grammar, in which grammatical items are defined as signs that are by convention discursively secondary and structurally dependent.
\end{abstract}

\section{Nøgleord}

determinativer, artikler, numeraler, agammatisme, grammatik

\section{Indledning: Agrammatisme og determinativpro- duktion}

Begrebet agrammatisme betegner et symptomkompleks, der kan findes i Brocas afasi. (1), hvor taleren beskriver det billede, der på dansk kaldes "Småkagetyveriet" (se Jensen 1992: 9), er et prototypisk eksempel på agrammatisk tale. 


$$
\begin{aligned}
& \text { Ja, ja ... dreng ... og pige ... og mor. fa ... kager ... og ja, valte ... stolen, } \\
& \ldots \text { ja, og ...ta- ...ta- ... tallelerken. Vasser op, ja (Jensen 1992: 9). }
\end{aligned}
$$

Menn \& Obler (1990) giver følgende tværsproglige definition:

"For cross-language studies, the definition of agrammatism must be framed in a fashion which is independent of the morphological and syntactic devices that any particular language may use. As a working basis, we take the features of slow rate and short sentence and phrase length as definitional; we also look for some 'limited use' of syntactic and morphological devices" (Menn \& Obler 1990: 3).

I de fleste europæiske sprog er det karakteristisk for agrammatisme, at grammatiske morfemer og ord bliver udeladt eller substitueret - det gælder fx artikler (se bl.a. Månsson \& Ahlsén 2002) - og at egentlige syntaktiske konstruktioner er få og simple (Bastiaanse \& Thompson 2012). Det er derfor oplagt (ikke kun terminologisk) at forsøge at forstå agrammatisme som et problem med grammatiske tegn, og denne tilgang til agrammatisme har længe været dominerende. Den ligger til grund for bl.a. Rosenberg og kollegaers dual route-teori (Rosenberg, Zurif, Brownell, Garrett \& Bradley 1985) og for Kolk \& Heeschens (1990) adaptation theory.

Siden 1990'erne er denne tilgang imidlertid blevet udfordret. En række neurolingvister har med Roelien Bastiaanse i spidsen foreslået, at agrammatisme - eller i hvert fald dele af det agrammatiske symptomkompleks - er udtryk for et grundlæggende problem med verber (Bastiaanse, Jonkers \& Moltmaker-Osinga, 1996). Studier af determinativproduktion spiller en central rolle for denne alternative tilgang (se Nielsen, Boye, Bastiaanse \& Michel Lange, 2019, for en udførlig diskussion). Man har argumenteret for, at problemer med produktionen af verber fører til problemer med produktionen af determinativer. I en undersøgelse af tysk agrammatisk tale fandt Ruigendijk \& Bastiaanse (2002) fx, at der blev produceret en større andel af determinativer, når der var et styrende verbum til stede, end når der ikke var. Forfatternes forklaring er, at udeladelsen af determinativer i agrammatisk tale ikke skyldes et problem med determinativer som sådan, men et problem, der har at gøre med produktionen af verber, der tilskriver determinativerne kasus. Imidlertid fandt Ruigendijk \& Baauw (2007) i en undersøgelse af hollandsk agrammatisk tale belæg for en helt modsat år- 
sagssammenhæng: Der blev produceret en større andel af styrende verber, når der var et determinativ til stede, end når der ikke var.

Det lader altså til, at ligesom problemer med produktionen af verber kan føre til problemer med determinativproduktion, så kan problemer med determinativproduktion føre til problemer med produktionen af verber. Det betyder, at det er svært at fastholde idéen om en ensrettet kausal relation mellem verbum- og determinativproblemer. Man kan let forestille sig, at begge problemer har en tredje årsag.

Dertil kommer, at de ovenfor omtalte studier stort set alle fokuserer på grammatiske determinativer, især artikler, og ikke kontrasterer disse med deres nære leksikalske slægtninge, fx numeraler. Studierne repræsenterer som sagt et alternativ til forsøgene på at forstå agrammatisme som et problem med grammatiske elementer, men det kan ikke udelukkes, at begge tilgange har noget for sig. Det kan med andre ord ikke udelukkes, at personer med agrammatisme har problemer med såvel verber som grammatiske elementer. I deres undersøgelse af hollandsk agrammatisk tale skelnede Ruigendijk \& Baauw (2007) mellem to grupper af determinativer: 1) artikler, demonstrativer og possessiver, og 2) numeraler og kvantorer. Undersøgelsen viste, at kun den første gruppe var problematisk for personer med agrammatisme. Det er uklart, hvordan deres skelnen relaterer sig til sondringen mellem grammatiske og leksikalske elementer, men deres resultater viser, at agrammatisme ikke kun kan være et problem med verbumproduktion, og det genrejser spørgsmålet: Er der en særskilt effekt af et ords status som grammatisk eller leksikalsk i determinativproduktionen hos agrammatiske talere?

Dette spørgsmål er udgangspunkt for nærværende artikel. I afsnit 2 gennemgår vi en ny undersøgelse, der besvarer spørgsmålet bekræftende. I afsnit 3 udvider vi derpå perspektivet og gennemgår en række andre undersøgelser, der viser, at problemerne med grammatiske tegn i agrammatisme har en parallel i ikke-hjerneskadedes sprog. I afsnit 4 fortolker vi resultaterne af alle disse undersøgelser i lyset af Boye \& Harders teori (2012) om forskellen på grammatiske og leksikalske elementer og de implikationer, den har for en forståelse af, hvad grammatikproblemer er.

\section{Grammatiske kontra leksikalske determinativer i agrammatisk afasi}

Undersøgelsen af, om der er en særskilt effekt af kontrasten mellem grammatiske og leksikalske ord i determinativproduktionen hos agrammatiske 
talere, er afrapporteret i Nielsen \& al. (2019). Forfatterne anvendte en version af forsøgsdesignet i Michel Lange, Messerschmidt \& Boye (2018) (se afsnit 3), der var tilpasset til personer med afasi. Dette design er bygget op omkring minimalpar som dem i (2) og (3), der kontrasterer de ubestemte artikler en og et med disses nærhomonyme numeraler (anført med accent).

(2a) En grøn firkant.

(2b) Én grøn firkant.

(3a) Et grønt brev.

(3b) Ét grønt brev. (fælleskønsartikel)

(fælleskønsnumerale)

(intetkønsartikel)

(intetkønsnumerale)

Artiklerne og numeralerne er nært relaterede. Begge slags ord varierer i genus, og begge kongruerer i konstruktioner som dem i (2) og (3) med nominalsyntagmets hovedsubstantiv. De indtager endvidere omtrent samme prænominale position, og artiklen er historisk set dannet af numeralet. De to slags ord adskiller sig dog mht. trykmuligheder, frekvens og strukturel status (dvs. om de er grammatiske eller leksikalske). Det sidste er centralt for forsøgsdesignet. Ifølge Boye \& Harders (2012) teori om kontrasten mellem grammatisk og leksikalsk status er artiklerne grammatiske ord, mens numeralerne er leksikalske: Bortset fra i korrigerende kontekster er det kun de sidstnævnte, der kan stå alene i et nominalsyntagme og bringes i fokus vha. fx en fokuspartikel som kun. Det er således kun numeralerne, der opfylder Boye \& Harders kriterier for leksikalsk ("potentielt diskursivt primær") status.

$\begin{array}{ll}\text { (4a) *Jeg har kun en/et. } & \text { (artikel = grammatisk) } \\ \text { (4b) Jeg har kun én/ét. } & \text { (numerale = leksikalsk) }\end{array}$

Minimalparrene i (2) og (3) kontrasterer altså grammatiske og leksikalske ord. Vi refererer til de to slags ord som hhv. grammatiske og leksikalske determinativer. Det kan diskuteres, om numeraler er determinativer i streng forstand, men den diskussion er irrelevant her. Det afgørende er, at verbets rolle som kasustilskriver er neutraliseret i det omtalte design (jf. afsnit 1): Artikler og numeraler må opføre sig ens mht. kasustilskrivning. Ingen af de to slags ord tilskrives synlig kasus i dansk, og den, der vil hævde, at de tilskrives usynlig kasus, må hævde, at begge slags ord gør det, eftersom både artikler og numeraler tilskrives synlig kasus i relaterede sprog som tysk: I (5) kan akkusativformen einen fungere som både artikel og numerale. 
(5) Ich habe einen Wagen.

'Jeg har en bil'.

Artikler og numeraler blev eliciteret som del af nominalsyntagmer vha. tegninger af forskellige objekter, der var referenter for de eliciterede nominalsyntagmer. Hver tegning gengav enten et objekt (ved elicitering af numeraler) eller to ens objekter i samme farve (ved elicitering af artikler). Tegningerne varierede i farve. Halvdelen af de eliciterede nominalsyntagmer var fælleskøn, og halvdelen intetkøn. Elicitationsdesignet var som følger (jf. figur 1): Forsøgsdeltagerne hørte først en stemme sige jeg har efterfulgt af et nominalsyntagme, der benævnede antal, farve og type af et objekt, $\mathrm{fx}$ sætning (6) og (7).

(6) Jeg har to røde breve.

(7) Jeg har et grønt brev.

Samtidig så de på en computerskærm en tegning af referenten til nominalsyntagmet, fx en tegning af to røde breve. Derefter hørte de samme stemme stille et af to spørgsmål (8)-(9).

(8) Hvor mange har du?

(9) Hvad har du?

Numeraler blev eliciteret ved spørgsmålet i (8) og den samtidige forevisning af en tegning nummer to, der gengav samme type og farve objekt som den første tegning, men som kun gengav ét eksemplar af objektet i kontrast til den første tegnings to eksemplarer. Fx forventedes forsøgsdeltagerne mundtligt at producere ét rødt brev i forlængelse af (6) og (8). Artikler blev eliciteret ved spørgsmålet i (9) og den samtidige forevisning af en tegning nummer to, der gengav samme type objekt som den første tegning og samme antal af objektet, men som gengav det med en anden farve end tegning nummer et. Fx blev i forlængelse af (7) og (9) nominalsyntagmet et rodt brev eliciteret.

Der deltog fem personer diagnosticeret med Brocas afasi (som er associeret med agrammatisme) og som kontrolgruppe fire ikke-hjerneskadede personer. For hver forsøgsperson blev (blandt andet) antallet af determinativudeladelser (fx rodt brev i stedet for et rodt brev eller ét rødt brev) og antallet af kønsbaserede determinativsubstitutioner (fx en rødt brev i stedet for et rødt brev eller én rodt brev i stedet for ét rødt brev) registreret. 


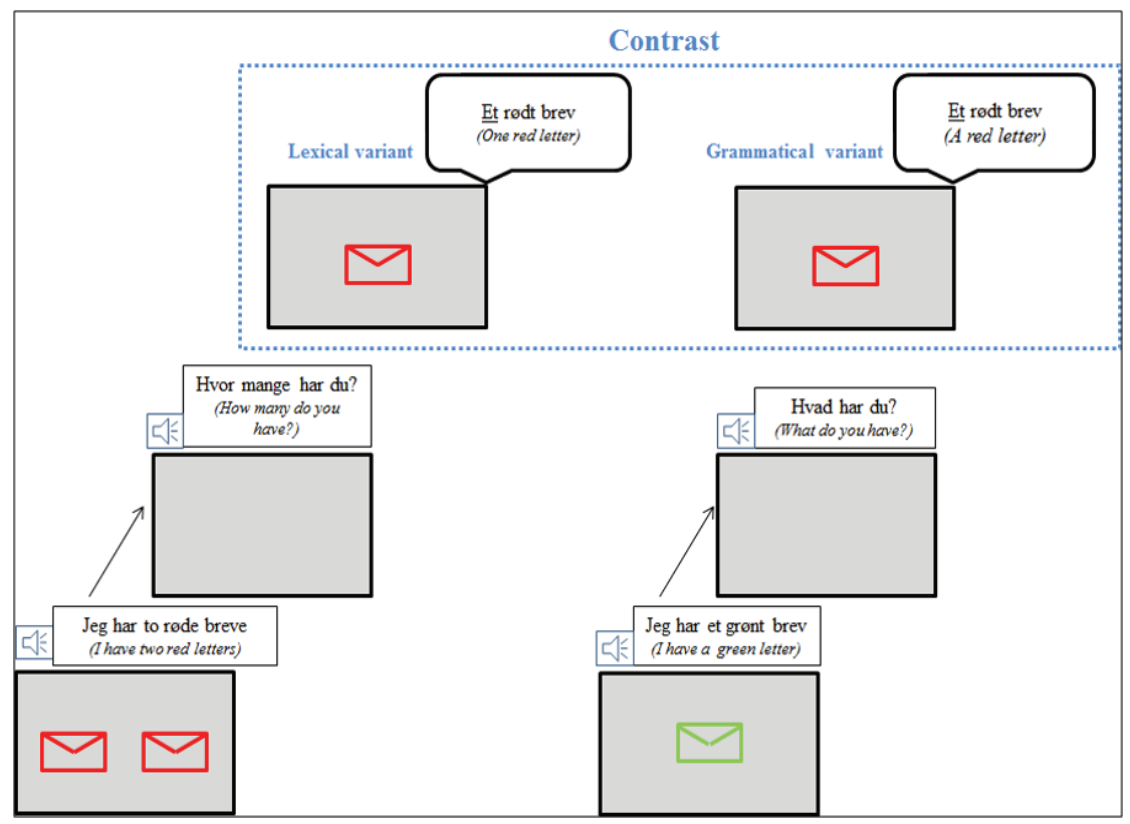

Figur 1: Determinativproduktionsstudiets forsøgsdesign (Michel Lange, Messerschmidt \&̊ Boye 2018).

Rationalet bag dette forsøg er som følger: Hvis der er en særskilt effekt af kontrasten mellem grammatiske og leksikalske ord i determinativproduktionen hos agrammatiske talere, må dette vise sig i determinativudeladelserne og/eller -substititionerne. Hvis med andre ord personer med agrammatisme faktisk har problemer med grammatiske ord, forventer vi, at de udelader flere grammatiske determinativer (artikler) end leksikalske (numeraler). Desuden forventer vi, at de producerer flere kønsbaserede substitutioner af både grammatiske og leksikalske determinativer. Denne anden forventning er baseret på, at køn i begge slags determinativer er kongruensbetinget og dermed uomtvisteligt et grammatisk fænomen: Bortset fra i korrigerende kontekster er kongruensens funktion aldrig diskursivt primær - pointen med at sige et rodt brev er aldrig at kommunikere, at betydningerne af et og rød vedrører betydningen af brev. Kongruensens funktion er med andre ord diskursivt sekundær pr. konvention og dermed ifølge Boye \& Harders (2012) teori grammatisk.

Resultaterne af forsøget bekræfter, at der er en særskilt effekt af kontrasten mellem grammatiske og leksikalske ord. Som det fremgår af figur 2, udelod forsøgsdeltagerne med Brocas afasi signifikant flere grammatiske 


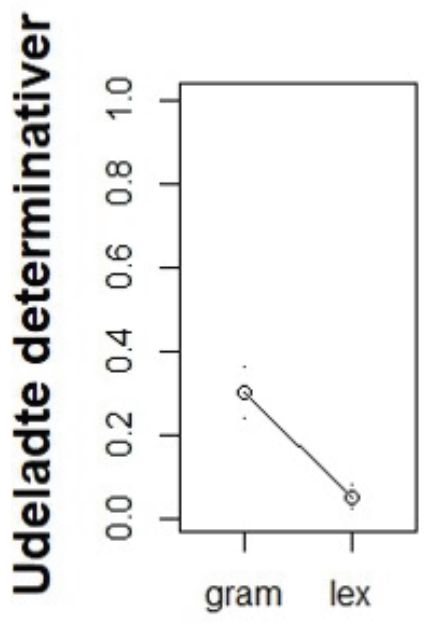

Afasi

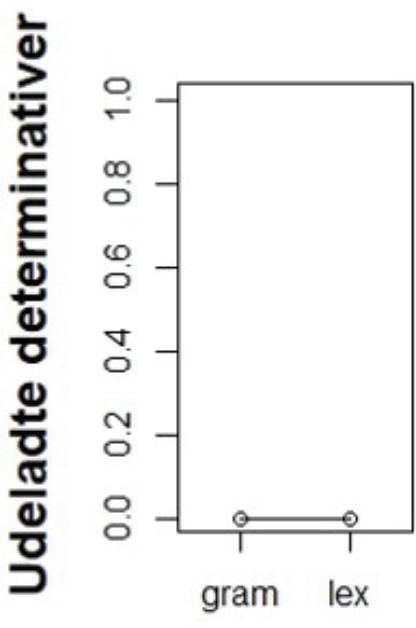

Kontrol

Figur 2: Andelen af udeladte grammatiske (gram) og leksikalske (lex) determinativer hos personer med Brocas afasi og hos en kontrolgruppe af raske forsogsdeltagere (tilpasset fra Nielsen et al., 2019).

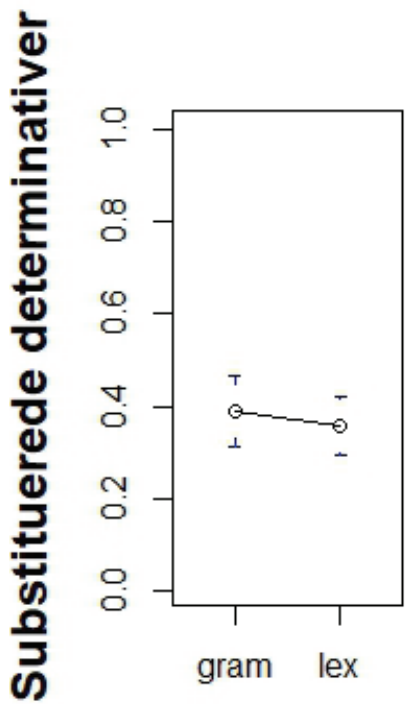

Afasi

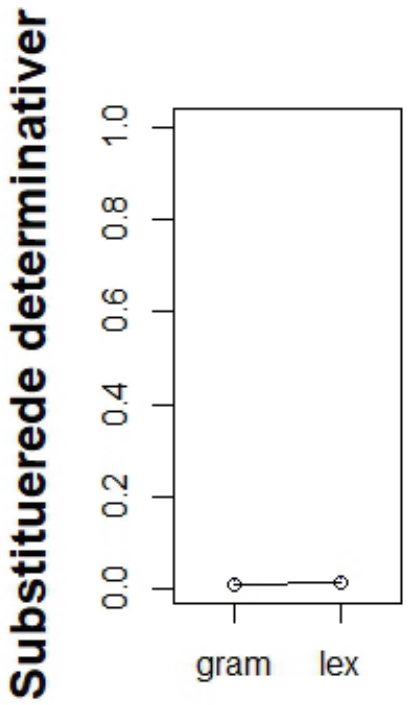

Kontrol

Figur 3: Andelen af konsbaserede determinativsubstitutioner hos personer med Brocas afasi og hos en kontrolgruppe af raske forsøgsdeltagere (tilpasset fra Nielsen et al., 2019). 
determinativer end den raske kontrolgruppe, men ikke signifikant flere leksikalske determinativer.

Som det fremgår af figur 3, producerede deltagerne med Brocas afasi signifikant flere kønsbaserede determinativsubstitutioner end den raske kontrolgruppe, mens der ikke var signifikant forskel på andelene af substituerede grammatiske og leksikalske determinativer.

Resultaterne kan ikke forklares ved de frekvensforskelle, der er på artikler og numeraler, for artiklerne er langt mere frekvente end numeralerne, og alt tyder på, at høj frekvens virker fremmende på evnen til at producere ord hos personer med afasi (Martinéz-Ferreiro, Boye \& Bastiaanse, 2019). Der er store individuelle forskelle $\mathrm{i}$ både udeladelser og substitutioner i gruppen af deltagere med Brocas afasi (se Nielsen et al., 2019), men de rokker ikke ved den overordnede konklusion på undersøgelsen: Personer med Brocas afasi ser ud til at have problemer med grammatiske determinativer (artikler) og med det grammatiske element i både grammatiske og leksikalske determinativer (kønskongruens), men de har ikke problemer med determinativer som sådan.

\section{Grammatiske kontra leksikalske determinativer hos ikke-hjerneskadede}

Det rejser spørgsmålet, om grammatiske determinativer også er problematiske for ikke-hjerneskadede. Det tyder en række nylige undersøgelser på.

Michel Lange, Messerschmidt \& Boye (2018) udviklede det forsøgsparadigme, der blev anvendt i det ovenfor omtalte afasieksperiment. De anvendte en version, der ikke var tilpasset personer med afasi, men som i modsætning til den version, der blev anvendt i Nielsen et al. (2019), indeholdt "fillers". Paradigmet blev brugt til at teste 21 ikke-hjerneskadede dansktalende. Igen skulle forsøgsdeltagerne mundtligt producere nominalsyntagmer med grammatiske eller leksikalske determinativer i forlængelse af sætningerne (6) og (8) eller (7) og (9) (jf. figur 1). De centrale resultater bestod af reaktionstider (tiden fra forevisning af den eliciterende tegning, der ledsagede (8) og (9), til forsøgsdeltagerens voice onset) og akkurratesse (om de eliciterede nominalsyntagmer blev produceret korrekt). Baseret på Boye \& Harders (2012) teori om forskellen på grammatiske og leksikalske tegn forventedes det, at nominalsyntagmer med grammatiske determinativer (artikler) ville være forbundet med længere reaktionstider og mindre akkuratesse end nominalsyntagmer med leksikalske determinativer. Ifølge Boye \& Harder (2012) adskiller grammatiske tegn sig fra leksikalske ved 
pr. konvention at være diskursivt sekundære og derfor også afhængige af kombination med værtstegn, i forhold til hvilke de kan optræde diskursivt sekundært. Forventningen var, at grammatiske tegns ekstra dependens (deres afhængighed af kombination) ville være forbundet med en ekstra processeringsomkostning, som ville vise sig i ekstra produktionstid, og at både den ekstra dependens og den diskursivt sekundære status ville vise sig i mindre akkuratesse (eftersom den ekstra dependens indebærer en større processeringsbyrde, mens den diskursivt sekundære status ville motivere, at forsøgsdeltagerne gør sig mindre umage med produktionen af nominalsyntagmer med grammatiske determinativer).

Resultaterne af undersøgelsen var som følger: Der var ingen forskel i akkuratesse på den grammatiske og leksikalske betingelse, hvilket rimeligvis er udtryk for en lofteffekt, der skyldes, at opgaven er meget let for ikke-hjerneskadede. Den halvdel af forsøgsdeltagerne, der havde de langsomste reaktionstider, udviste en signifikant forskel mht. reaktionstider, der går imod forventningen: Produktionen af nominalsyntagmer med grammatisk determinativ (artikel) var forbundet med kortere reaktionstider end produktionen af syntagmer med leksikalsk determinativ. Dette resultat kan forstås som en frekvenseffekt: Grammatiske determinativer er langt mere frekvente end leksikalske, og høj frekvens er forbundet med kortere reaktionstider i sprogproduktion (se Michel Lange, Messerschmidt \& Boye 2018 for detaljer). Den halvdel af forsøgsdeltagerne, der havde de hurtigste reaktionstider, og som derfor kan antages at repræsentere den kanoniske eller mest effektive processeringssti, udviste imidlertid en signifikant forskel, der bekræftede forventningen: Produktionen af nominalsyntagmer med grammatisk determinativ (artikel) var forbundet med længere reaktionstider end produktionen af syntagmer med leksikalsk determinativ. Det tyder som sagt på, at produktionen af grammatiske determinativer er forbundet med en større processeringsomkostning end produktionen af leksikalske.

Ishkhanyan, Boye \& Mogensen (2018) peger i samme retning. Igen blev forsøgsdesignet fra Michel Lange, Messerschmidt \& Boye (2018) anvendt, men denne gang blev det tilføjet en belastning af arbejdshukommelsen: Efter hver besvarelse af et af eliciteringsspørgsmålene i (8) og (9), hørte forsøgsdeltagerne et substantiv, og efter fire, fem, seks og syv besvarelser af eliciteringsspørgsmål måtte de forsøge at gengive de hhv. fire, fem, seks og syv seneste substantiver, de havde hørt, i den rette rækkefølge. Det således modificerede forsøgsparadigme blev brugt til at teste 21 ikke-hjerneskadede dansktalende. Reaktionstider og akkuratesse blev registreret på samme måde 
som i Michel Lange, Messerschmidt og Boye (2018), og igen forventedes det (blandt andet; se Ishkhanyan, Boye \& Mogensen 2018), at produktionen af nominalsyntagmer med grammatisk determinativ ville være forbundet med længere reaktionstider og mindre akkuratesse end produktionen af nominalsyntagmer.

Resultaterne var som følger: Der var ikke nogen signifikant forskel på reaktionstiderne i den grammatiske og leksikalske betingelse (der blev dog ikke skelnet mellem langsomme og hurtige forsøgsdeltagere som i Michel Lange, Messerschmidt \& Boye (2018)), men i modsætning til resultaterne i Michel Lange, Messerschmidt \& Boye (2018) var der en forskel i akkuratesse: Nominalsyntagmerne med grammatisk determinativ blev produceret signifikant mindre akkurat - dvs. med flere fejl - end dem med leksikalsk determinativ. Hvor størstedelen af fejlene (60\%) i den leksikalske betingelse bestod i disfluenser (dvs. pauser og andre brud på i øvrigt flydende tale), bestod ydermere langt størstedelen af fejlene $(80 \%)$ i den grammatiske betingelse af udeladelser af det grammatiske determinativ. Dvs. at nominalsyntagmeproduktionen hos ikke-hjerneskadede med arbejdshukommelsesbelastning minder om den, der er karakteristisk for forsøgsdeltagerne med afasi i Nielsen et al. (2019).

Grammatiske determinativer er altså problematiske ikke blot for personer med Brocas afasi, men også for ikke-hjerneskadede, mens leksikalske determinativer er relativt uproblematiske for begge grupper af personer. Spørgsmålet er nu, om det er en idiosynkratisk egenskab ved grammatiske determinativer, der gør dem problematiske, eller om det er det, at de er grammatiske, der gør dem problematiske.

Alt tyder på, at det sidste er tilfældet. For det første forudsiger teorien i Boye \& Harder (2012), at grammatiske tegn skulle være sværere at processere end grammatiske (jf. diskussionen ovenfor). For det andet er der dokumentation for en parallel til forskellen på grammatiske og leksikalske determinativer i en anden ordklasse: verber. Michel Lange, Messerschmidt, Harder, Siebner \& Boye (2017) kontrasterede produktionen af homonyme hjælpeverber (grammatiske) og fuldverber (leksikalske) i et eksperiment, der minder om de ovenfor omtalte. Hjælpeverbet have blev kontrasteret med fuldverbet have som i (10), og hjælpeverbet $f a ̊$ med fuldverbet $f a ̊$ som i (1 1).

(10a) Maja har brugt en computer.

(10b) Maja har en brugt computer. 
(11a) Marie får forbedret et styresystem.

(11b) Marie får et forbedret styresystem.

Sætningerne i (10) og (11) fungerede som stimuli. Efter at hørt sådanne sætninger fik forsøgsdeltagerne spørgsmålet i (12) (idet propriet blev varieret fra spørgsmål til spørgsmål), og de blev vha. en farvekode instrueret i at svare bekræftende eller afkræftende.

\section{(12) Hvad med Anne?}

Dermed blev der eliciteret sætninger af følgende typer, hvoraf halvdelen fungerer som repetitioner af sætninger med hjælpeverbum (10a, 11a), mens den anden halvdel fungerer som repetitioner af fuldverbum (10b, 11b).

(13a) Det har hun også.

(13b) Det har hun ikke.

(14a) Det får hun også.

(14b) Det får hun ikke.

Det vil sige, at grammatiske og leksikalske verber blev kontrasteret i identiske sproglige strenge.

Dette forsøgsparadigme blev tilføjet "fillers" og brugt til at teste 24 ikkehjerneskadede dansktalende, hvoraf en dog systematisk brugte gøre som verbum vicarium i stedet for få i sætninger som (14a, b) (det gør hun også; det gor hun ikke) og derfor blev frasorteret. De centrale resultater bestod af reaktionstider (tiden fra forevisningen af den farvekode, der ledsagede eliciteringsspørgsmålene som det i (12), til forsøgsdeltagerens voice onset) og akkurratesse (om de eliciterede sætninger blev produceret korrekt). Baseret på Boye \& Harder (2012) forventedes det, at sætninger, der repeterede et grammatisk verbum, var forbundet med længere reaktionstider og mindre akkuratesse end sætninger, der repeterede et leksikalsk verbum. Begge forventninger blev indfriet med signifikante forskelle på den grammatiske og den leksikalske betingelse.

Det tyder altså på, at grammatiske tegn er vanskeligere at producere end leksikalske, både når det drejer sig om determinativer, og når det drejer sig om verber. Ligesom det er tilfældet med resultaterne af determinativforsøgene, kan resultaterne af verbumforsøget ikke forklares med henvisning til frekvensforskelle. Dels er der ikke store frekvensforskelle på de grammati- 
ske og leksikalske verber, vi undersøgte, dels er forskellene modsatrettede: Grammatisk have er omtrent dobbelt så hyppigt som leksikalsk have, mens grammatisk $f a ̊$ kun er omtrent en syvendedel så hyppigt som leksikalsk $f a ̊$ (Michel Lange et al. 2017). Der kan tænkes andre måder at forklare resultaterne på. Man kunne fx forestille sig, at de længere reaktionstider og den mindre akkuratesse i produktionen af sætninger, der repeterer sætninger med hjælpeverbum, skyldes at de repeterede sætninger er strukturelt eller konceptueltsemantisk mere komplekse end sætninger med fuldverbum. Sådanne spekulationer er imidlertid posthoc og teoretisk uforankrede, og de muliggør i modsætning til teorien i Boye \& Harder (2012) ikke en generalisering over både verbumeksperimentet og de tre determinativeksperimenter.

\section{Hvad er årsagen til vanskeligheder med produk- tionen af grammatiske tegn?}

I det følgende diskuteres implikationerne af de resultater, der er gennemgået ovenfor, for vores forståelse af sprogprocessering i almindelighed og Brocas afasi i særdeleshed. Diskussionen er baseret på Boye \& Harders (2012) teori om forskellen på grammatiske og leksikalske tegn. Ifølge denne teori er der to afgørende forskelle på de to slags tegn. For det første er grammatiske tegn pr. konvention diskursivt sekundære (baggrund) i forhold til syntagmatisk relaterede tegn, mens leksikalske pr. konvention har potentialet til at være diskursivt primære (forgrund). Dvs. at kun leksikalske tegn kan udtrykke hovedsagen i en sproglig meddelelse - så længe konventionerne ikke brydes (i korrektive kontekster, hvor et grammatisk tegn kontrasteres med et andet). For det andet er grammatiske tegn dependente i den forstand, at de kræver kombination med et "værtstegn", mens leksikalske tegn ikke nødvendigvis har en sådan dependens. Denne anden forskel følger af den første: Deres dependens kan forstås som en konsekvens af, at de kræver et "værtstegn", i forhold til hvilket de kan være diskursivt sekundære.

Resultaterne af undersøgelserne, der er gennemgået ovenfor, kan forstås i lyset af disse to forskelle på grammatiske og leksikalske tegn (Boye, Bastiaanse, Harder \& Martínez-Ferriero, under revision). Det forhold, at grammatiske tegn pr. konvention er sekundære, motiverer for det første tendensen til, at de udelades af personer med Brocas afasi eller arbejdshukommelsesbelastning. Både arbejdshukommelsesbelastning og Brocas afasi må antages at indebære en reduktion af kognitive ressourcer, og udeladelsen af grammatiske determinativer kan ses som en tilpasning til en sådan 
reduktion: Der er ikke ressourcer til at producere fuldbyrdede sproglige strenge, og grammatiske determinativer udelades, fordi de som sekundære elementer ikke er kommunikativt afgørende. Bemærk i den forbindelse, at de leksikalske determinativer i modsætning til de grammatiske netop er kommunikativt afgørende i determinativeksperimentet: Det er numeralerne, der leverer det direkte svar på det leksikalske eliciteringsspørgsmål Hvor mange har du? i (8).

De grammatiske determinativers sekundære status motiverer endvidere tendensen hos personer med Brocas afasi til at lave kongruensfejl: Som en kompensation for reduktionen af kognitive ressourcer (se ovenfor) allokeres der færre ressourcer til produktionen af grammatiske tegn, herunder kongruensmarkører, fordi disse er diskursivt sekundære og derfor ikke kommunikativt afgørende.

Derimod er der ikke en oplagt forbindelse mellem diskursivt sekundær status og den større processeringsbyrde, der er forbundet med produktionen af grammatiske tegn. Man kunne overveje, om sekundær status er forbundet med en længere aktiveringstid, og om det er denne længere aktiveringstid, der slår igennem i de længere reaktionstider hos de hurtigst reagerende forsøgsdeltagere i eksperimentet i Michel Lange, Messerschmidt \& Boye (2018). De kortere reaktionstider hos de langsomst reagerende deltagere kunne så ses som en følge af, at de grammatiske determinativer er højfrekvente og derfor har en kortere aktiveringstid.

Det er imidlertid mere ligetil at forklare de længere reaktionstider for grammatiske determinativer med henvisning til den anden af de to forskelle på grammatiske og leksikalske tegn, dependensforskellen: De grammatiske determinativer kræver kombination med et "værtstegn", og denne kombination indebærer en ekstra processeringsbyrde i forhold til leksikalske tegn. En sådan forklaring er i tråd med med eksisterende psykolingvistiske modelleringer af sprogproduktion: Planlægningen af grammatiske elementer forudsætter ifølge modellerne i Garrett (1975), Bock (1987) og Levelt (1989) planlægningen af leksikalske elementer.

Dependensforskellen kan muligvis også forklare tendenserne hos personer med Brocas afasi til at udelade grammatiske determinativer og til at lave kongruensfejl. Hvis Broca-hjerneområdet antages at understøtte evnen til at sætte enkelttegn sammen til komplekse tegn, vil en skade i dette område særligt gå ud over grammatiske tegn, da de kræver sammenkobling med andre tegn. Den vil endvidere gå ud over verber, i den udstrækning de kræver argumenter, så her er en mulig samlet forklaring på, at Brocas afasi er forbundet med problemer med både produktionen af verber (se afsnit 
1) og produktionen af grammatiske tegn. Dependensforskellen forklarer imidlertid dårligt, at også personer med arbejdshukommelsesbelastning har en tendens til at udelade grammatiske determinativer. Der er, så vidt vi kan se, ingen oplagt grund til, at manglende lagerplads skulle føre til udeladelse af dependente tegn.

Resultaterne, der er fremlagt i denne artikel, lader sig altså ikke forstå alene med henvisning til dependensforskellen eller diskursprominensforskellen på grammatiske og leksikalske tegn. Kun hvis begge forskelle inddrages, opnås en dækkende forklaring: Produktionen af grammatiske tegn afhænger både af en evne til at kombinere grammatiske tegn med værtstegn og af et overskud ( $\mathrm{fx}$ i arbejdshukommelsen) til at producere ikke blot diskursivt primære, men også diskursivt sekundære tegn. Denne forklaring indebærer, at forholdet mellem sprogproduktion og sprogperception er asymmetrisk: Afsenderen investerer lidt ekstra i de grammatiske tegn og letter dermed processeringsbyrden for modtageren. Modtagerens processeringsarbejde bliver lettet på to måder. For det første får hun meddelt noget information pr. kode, som hun ellers skulle have processeret sig frem til på baggrund af konteksten. For det andet făr hun en delvis prioritering af delene af meddelelsen, i og med at de grammatiske tegn koder information, der er mindre vigtig og kan produceres overfladisk.

\section{Konklusion}

I denne artikel har vi gennemgået en række undersøgelser af produktionen af danske determinativer. Undersøgelserne bygger alle på en sondring mellem grammatiske determinativer (ubestemte artikler) og leksikalske (numeraler), og de viser, at sondringen er signifikant for forståelsen af determinativproduktion både hos personer med Brocas afasi og hos ikke-hjerneskadede. Mere specifikt viser undersøgelserne følgende: Undersøgelsen af personer med Brocas afasi viser, at disse har en tendens til at udelade grammatiske determinativer, men ikke leksikalske, og til at lave kongruensfejl. Den samme tendens udviser ikke-hjerneskadede personer i en undersøgelse, hvor arbejdshukommelsen belastes. I en undersøgelse, hvor arbejdshukommelsen ikke belastes, er der en tendens til, at ikke-hjerneskadede er længere tid om at producere grammatiske determinativer end leksikalske, hvilket tyder på, at produktionen af grammatiske determinativer er forbundet med større processeringsomkostninger. Denne tendens er dog kun dokumenteret hos de hurtigstreagerende talere, der kan antages at repræsentere den kanoniske eller mest effektive processeringssti. 
Vi har endvidere gennemgået en undersøgelse af produktionen af verber hos ikke-hjerneskadede. Denne undersøgelse viser, at der er en tendens til, at ikke-hjerneskadede er længere tid om at producere grammatiske verber end leksikalske (denne tendens findes hos både hurtigt- og langsomtreagerende talere). Der er altså resultatmæssigt tale om en pendant til undersøgelsen af determinativproduktionen hos ikke-hjerneskadede, og eksistensen af denne pendant er et argument for, at den afgørende faktor i de resultater, der vedrører determinativer, er forskellen på grammatisk kontra leksikalsk status - og ikke andre forskelle på artikler og numeraler.

Vi har argumenteret for, at de empiriske kontraster mellem produktionen af grammatiske og leksikalske determinativer kan forstås med henvisning til de centrale forskelle, der ifølge Boye \& Harder (2012) er på grammatiske og leksikalske tegn: Førstnævnte er pr. konvention diskursivt sekundære og dependente i forhold til et "værtstegn", mens sidstnævnte pr. konvention er potentielt diskursivt primære og ikke nødvendigvis dependente. Hverken de grammatiske tegns sekundære status eller deres dependens forklarer selvstændigt alle de empiriske kontraster, men de gør det i forening.

\section{Om forfatterne}

Kasper Boye, lektor i lingvistik, Institut for Nordiske Studier og Sprogvidenskab, Københavns Universitet.

Sarah Rosenbech Nielsen, cand.mag. i lingvistik, Associate Linguist, Google (via Adecco).

Byurakn Ishkhanyan, postdoc, Institut for Kommunikation og Kultur, Aarhus Universitet.

\section{Litteratur}

Bastiaanse, R., Jonkers, R., \& Moltmaker-Osinga, U. (1996): Aspects of lexical verbs in the spontaneous speech of agrammatic and anomic patients. I:Jonkers, R., Kaan, E, \& Wiegel, A. (red.), Language and cognition, 5. Groningen: University of Groningen, 13-26.

Bastiaanse, R., \& Thompson, C. K. (red.) (2012): Perspectives on agrammatism. New York: Psychology Press.

Bock K. (1987): An effect of the accessibility of word forms on sentence structures. Fournal of memory and language, 26 (2), 119-137.

Boye, K., Bastiaanse, R., Harder, P. \& Martínez-Ferreiro, S. (under revision). Agrammatic aphasia in a usage-based theory of grammar. 
Boye, K. \& Harder, P. (2012): A usage-based theory of grammatical status and grammaticalization. Language 88(1), 1-44.

Garrett, M.F. (1975): The analysis of sentence production. I: Bower, G. (red.), Psychology of learning and motivation. New York: Academic Press, 133-177.

Ishkhanyan, B., Boye, K. \& Mogensen, J. (2018): The Meeting Point: Where Language Production and Working Memory Share Resources. Fournal of psycholinguistic research. DOI: 10.1007/s10936-018-9589-0.

Jensen, L.R. (1992): Afasi - at miste sproget helt eller delvist efter en hjerneskade. Mål og Male, 15(4), 6-12.

Kolk, H., \& Heeschen, C. (1990): Adaptation symptoms and impairment symptoms in Broca's aphasia. Aphasiology ,4(3), 221-231.

Levelt, W.J.M. (1989): Speaking: From intention to articulation. Cambridge: The MIT Press.

Martínez-Ferreiro, S., Boye, K. \& Bastiaanse, R. (2019). Functional and usagebased approaches to aphasia: the grammatical-lexical distinction and the role of frequency. Aphasiology. DOI: 10.1080/02687038.2019.1615335.

Menn, L. \& Obler, L. (1990): Cross-language data and theories of agrammatism. I: Menn, L. \& Obler, L. (red.), Agrammatic aphasia: A cross language narrative sourcebook. Amsterdam: John Benjamins, 1369-1380.

Michel Lange, V., Messerschmidt, M., \& Boye, K. (2018): Contrasting Grammatical and Lexical Determiners. Fournal of psycholinguistic research, 47(4), 1-16.

Michel Lange, V., Messerschmidt, M., Harder, P., Siebner, H. R., \& Boye, K. (2017): Planning and production of grammatical and lexical verbs in multi-word messages. PLoS ONE 12 (11), e0186685.

Månsson, A.C., \& Ahlsén, E. (2001): Grammatical features of aphasia in Swedish. Fournal of Neurolinguistics, 14(2), 365-380.

Nielsen, S.R., Boye, K., Bastiaanse, R. \& Lange, V.M. (2019). The production of grammatical and lexical determiners in Broca's aphasia. Language, Cognition and Neuroscience, DOI: 10.1080/23273798.2019.1616104.

Rosenberg, B., Zurif, E., Brownell, H., Garrett, M., \& Bradley, D. (1985): Grammatical class effects in relation to normal and aphasic sentence processing. Brain and Language, 26 (2), 287-303.

Ruigendijk, E. \& Bastiaanse, R. (2002): Two characteristics of agrammatic speech: Omission of verbs and omission of determiners, is there a relation? Aphasiology, 16 (4-6), 383-395.

Ruigendijk, E. \& Baauw, S. (2007): Syntactic and pragmatic aspects of determiner and pronoun production in Dutch agrammatic Broca's aphasia. Aphasiology, 21(6-8), 535-547. 